УДК 346.1: 346.24

DOI https://doi.org/10.32837/pyuv.v1i3(28).331

\author{
А.В. Подоляк \\ здобувач кафедри господарського права \\ Донецького національного університету ілені Василя Стуса, \\ адвокат \\ Адвокатського об’ єднання «ЕТЕРНАЛО»
}

\title{
ПРАВОВИЙ РЕЖИМ МАЙНА СУБ'СКТІВ УПРАВЛІННЯ У ДЕРЖАВНОМУ СЕКТОРІ ЕКОНОМІКИ
}

На сучасному етапі розвитку економічних відносин великої уваги заслуговують питання визначення правового режиму майна суб'єктів господарювання. Попри існування сьогодні досить міцного правового підгрунтя у вигляді норм Господарського і Цивільного кодексів України, низки спеціальних законів та підзаконних актів, необхідність подальшого теоретичного дослідження правового режиму майна окремих суб'єктів господарювання є актуальною. Отже, саме через правову категорію «правовий режим майна» можна розкрити правовий статус суб'єкта господарювання, визначити коло його майнових прав та обов'язків у процесі здійснення господарської діяльності.

Однак більш сучасно та повно регулюючи відносини, що існують в процесі створення та діяльності суб'єктів господарювання, Господарський кодекс України (далі - ГК України) та Цивільний кодекс України (далі - ЦК України) містять певні недоліки, які полягають у тому, що окремим видам суб'єктів господарювання присвячено недостатню кількість норм, які фактично не спроможні виконати регулятивну функцію права в цій сфері суспільних відносин. Не звертається достатньо уваги на регулювання відносин за участю суб' єктів господарювання державного або комунального секторів економіки при здійсненні некомерційної господарської діяльності, в тому числі таких учасників господарських відносин, як установи. Внаслідок цього правова природа, сутність і правовий режим майна цього виду суб'єктів господарювання залишаються на законодавчому рівні врегульованими мінімально, що не сприяє досягненню бажаної чіткості й визначеності у цих відносинах.

Норми ГК України встановлюють статус суб’єктів господарювання, заснованих державою, проте часто суперечать положенням ЦК України. Це не сприяє єдності правового регулювання відносин за участю юридичних осіб.

Нечисленні норми ЦК України лише в загальних рисах констатують право держави на створення юридичних осіб, право цих юридичних осіб здійснювати діяльність. Багато норм ЦК України є бланкетними і відсилають до інших нормативних актів щодо правового статусу юридичних осіб публічного права.
До того ж сьогодні сприйняття управління як форми впливу держави на господарювання фізичних і юридичних осіб не є актуальним, тому детермінація управління в такому ракурсі, як воно подане в праві господарського відання і праві оперативного управління, не може задовольняти сучасні вимоги.

В українській правовій науці окремі питання державної власності та управління нею, а також питання реалізації організаційно-господарських повноважень органами управління, певні аспекти правового режиму об'єктів права власності висвітлювалися у роботах К.І. Апанасенко, А.Г. Бобкової, О.А. Беляневич, Г.М. Будурової, О.М. Вінник, О.П. Віхрова, Р.А. Джабраілова, Є.О. Заруднєва, А.М. Захарченко, В.К. Мамутова, В.С. Мілаш, О.П. Подцерковного, Г.В. Пронської, В.А. Устименка та інших. Проте не досить дослідженою $€$ проблема визначення правового режиму майна публічних установ.

Метою роботи є обгрунтування пропозицій щодо правового режиму майна юридичних осіб публічного права, заснованих державою.

Конвенцією про захист прав людини і основоположних свобод (1950р.), ратифікованою Законом від 17 липня 1997 р. № 475/97-ВР, зокрема у ст. 1 Першого протоколу до неї (1952 р.), передбачене право кожної фізичної чи юридичної особи безперешкодно користуватися своїм майном. Не допускається позбавлення особи ї̈ власності інакше як в інтересах суспільства i на умовах, передбачених законом і загальними принципами міжнародного права. Визнається право держави на здійснення контролю за користуванням майном відповідно до загальних інтересів або для забезпечення сплати податків чи інших зборів або штрафів [1].

Ч. 3 ст. 13 Конституції України встановлює, що держава забезпечує захист прав усіх суб'єктів права власності і господарювання [2]. Певна конкретизація характеристик права власності як основного речового права у сфері господарювання закріплена у ст. 134 ГК України [3], у якій зазначено, що суб'єкт господарювання, який здійснює господарську діяльність на основі права власності на свій розсуд, одноосібно або спільно з іншими суб'єктами, володіє, користується і розпоряджа- 
ється належним йому майном, у тому числі має право надати майно іншим суб'єктам для використання його на праві власності, праві господарського відання чи праві оперативного управління, на основі інших форм правового режиму майна, передбачених ГК України. Правовий режим власності та правові форми реалізації права власності у сфері господарювання визначаються ГК України і законом.

Ч. 3 ст. 22 ГК України закріплює, що повноваження суб'єктів управління у державному секторі економіки - Кабінету Міністрів України, міністерств, інших органів влади та організацій - щодо суб'єктів господарювання визначаються законом. Так, наприклад, згідно зі ст. 20 Закону України «Про Кабінет Міністрів України» [4] основними повноваженнями КМ України є, зокрема, здійснення відповідно до закону управління об'єктами державної власності, у тому числі корпоративними правами. КМ делегує в установленому законом порядку окремі повноваження щодо управління зазначеними об'єктами міністерствам, іншим центральним органам виконавчої влади, місцевим державним адміністраціям та відповідним суб'єктам господарювання, а також подає Верховній Раді України пропозиції стосовно визначення переліку об’єктів права державної власності, що не підлягають приватизації.

Згідно з Розпорядженням Кабінету Міністрів України від 27 травня 2015 року № 662-р «Про схвалення стратегії підвищення ефективності діяльності суб'єктів господарювання державного сектору економіки» основне завдання Кабінету Міністрів України - це забезпечення ефективного управління активами на користь їх основного власника - українського народу. Держава в особі органів управління повинна бути професійним та відповідальним власником суб'єктів господарювання і зосереджувати свої зусилля на збільшенні вартості їх активів [5].

Право оперативного управління - це речове право суб'єкта господарювання, який володіє, користується та розпоряджається майном, закріпленим за ним власником (уповноваженим ним органом), для здійснення некомерційної господарської діяльності у межах, встановлених законом, а також власником майна (уповноваженим ним органом). Власник майна здійснює контроль за використанням і збереженням цього майна безпосередньо або через уповноважений ним орган i має право вилучати у суб'єкта господарювання надлишкове майно, а також майно, що не використовується установою, та майно, що використовується останньою не за призначенням (ст. 137 ГК України).

За радянських часів у правовій літературі була поширена думка, що управляти - це організовувати. Проте управління - це не тільки частина організаційної діяльності. Недоречно розширювати межі сфери організаційних відносин, оскільки вони є засобом, що його сторони використовують з метою упорядкування своїх основних (майнових та немайнових) відносин. В одних випадках організаційні відносини є лише передумовою виникнення, зміни або припинення правовідносин, а в інших - одним 3 елементів уже наявних правовідносин.

Управління майном інших осіб завжди охоплює відносини між двома сторонами, одна з яких є власником майна, що передається в управління, а інша - особою, яка реалізує майнове право власника шляхом використання правомочностей щодо володіння, користування й розпорядження майном у відповідному обсязі протягом певного терміну. При цьому зазначена тріада правомочностей виникає в цієї особи для здійснення їх не у власних інтересах, а лише в інтересах власника. Управління майном передбачає певний вплив або діяльність, яка здійснюється щодо майна з метою підтримувати його призначення, ефективно використовувати або зберігати.

Доречними вважаємо висновки щодо управління об'єктами державної власності Г.В. Пронської і O.M. Вінник, які зазначають, що, крім тріади правомочностей власника (володіння, користування і розпорядження) до складу правомочностей власника у сфері господарювання щодо суб'єктів управління у державному секторі економіки можна віднести і засновницькі, регулятивні, оперативно-управлінські, контрольні та охоронні повноваження, які реалізуються через функцію управління власністю [6, с. 604; 7, с. 209-211].

Слід зазначити, що ГК України не містить норм, які б безпосередньо встановлювали правовий режим майна публічних установ. Однак опосередковано аналіз ст. 131 ГК України дозволяе зробити висновок, що публічна установа як неприбуткова організація визнається суб'єктом некомерційного господарювання. Ця думка висловлюється в науковій літературі [8]. Відповідно до ч. 2 ст. 135 ГК за публічними установами закріплюється майно на праві оперативного управління.

Характеристика оперативного управління державним майном, згідно з якою правам володіння, користування та розпорядження майном протистоїть обов'язок інших осіб не перешкоджати здійсненню цих правомочностей, є однією із найскладніших проблем правової науки у зв'язку з їі нерозробленістю та неможливістю її порівняння із заснованою на багатовіковому досвіді розробкою права власності. Основним питанням, яке важко вирішити, є питання стосовно неможливості визнання публічних установ та підприємств власниками, оскільки це суперечить тезі про єдиний характер державної власності та про державу як власника всього державного майна. У цивілістич- 
ній літературі з приводу правового режиму майна установи склалися різні підходи. Одні правники вважають, що майно має належати установам на праві власності. При цьому певна група правників вважає такий підхід правильним саме для визначення правового режиму майна приватних установ незалежно від підстав отримання останнього. Інші правники взагалі вважають, що категорія права оперативного управління - це невід'ємна частина науково-понятійного апарату лише радянської цивілістичної теорії, тому навряд можна визнати дійсними положення елементів радянської економіки в умовах ринкової економіки сьогодення (вагома частка держави у цивільному обігу не може слугувати підгрунтям для цього, бо на сучасному етапі відсутня основна ознака державної економіки - наявність суб'єктів права, які мають домінантне становище над іншими суб'єктами зазначених відносин). Держава не може творити долю юридичних осіб, навіть тих, яких вона наділила своїм майном, оскільки вона виступає у цивільних правовідносинах нарівні з іншими суб'єктами [9].

Д. Лещенко дійшов висновку, що оперативне управління слід замінити фідуціарною власністю. Так, на думку вченого, майно, передане власником публічній установі, доходи, отримані при здійсненні нею прибуткової діяльності, повинні належати їй на праві довірчої власності (довірчого управління) [10]. Д. Лещенко пропонує за установами публічного права визнавати довірчу власність, а за приватними установами - право власності. А.М. Захарченко пропонує визнавати управління об'єктами державної власності як діяльність, що опосередковує здійснення прав i обов'язків державою як власником певних майнових об'єктів та засновником (учасником) державних підприємств, державних господарських об'єднань, установ, організацій і господарських товариств [11, с. 45].

Отже, одні вчені наполягають на необхідності перенесення в романо-германську правову систему, до якої належить і Україна, конструкції довірчої власності, а інші дотримуються протилежної думки. Прихильники концепції довірчої власності звертають увагу на те, що, оскільки договір довірчого управління належить до інституту зобов'язального права, то він зможе регулювати відносини, які за своєю сутністю є значно вужчими, ніж ті, які регулюються за допомогою інституту довірчої власності. Однак з даним варіантом теорії розщепленої власності не можна погодитись з ідеологічних міркувань. Так, романські правові системи визначають право власності як абсолютне право, як єдину систему прерогатив власника щодо володіння, користування та розпорядження, які підлягають розподілу (розщепленню) тільки у визначених випадках. Проте навіть у таких випадках конструкція права власності вважається неподільною, вона не допускає розподілу права власності та існування кількох власників одного об'єкта.

А.Г. Бобковою та О.Є Заруднєвим було проведене дослідження правових режимів майна, похідних від права власності, в Україні та Федеративній Республіці Німеччина. Так, вчені зазначають, що, розглядаючи питання правового режиму майна публічних підприємств і установ у ФРН, необхідно звернути увагу на $§ 63$ Бюджетного кодексу ФРН [12], згідно з яким придбання майна допускається тільки з метою його використання у виконанні покладених на державу завдань у певному проміжку часу. При цьому відчуження майна дозволяється тільки в разі відсутності необхідності у такому майні у передбачуваному майбутньому періоді часу. Отже, майно може передаватись у повне розпорядження німецьким державним i комунальним підприємствам за умови, що використання майна і розпорядження ним здійснюється в рамках цілей діяльності відповідного підприємства та відповідно до прийнятих бюджетів і економічних планів на рік. Водночас низка підприємств із неповною дієздатністю чи без дієздатності може користуватись переданим майном без права визначати частку такого майна або з правом визначати ії відповідно до локального нормативного акта. Наведені особливості правового режиму майна державних і комунальних підприємств дозволяють порівняти їх із закріпленими в ГКу режимами майна. Німецькі дієздатні підприємства володіють майном на підставах, які певною мірою схожі на українське право господарського відання, адже і в ФРН, і в Україні в такому випадку ідеться про володіння, користування і розпорядження майном у рамках цілей підприємства. Однак згідно зі ст. 74 ГКУ майно закріплюється на праві господарського відання за державними комерційними підприємствами, а в Німеччині обмежений режим розпорядження майном застосовується до некомерційних підприємств. Що стосується недієздатних підприємств у ФРН (або підприємств з обмеженою дієздатністю), то застосований ними режим майна найбільшою мірою можна прирівняти до українського права оперативного відання, коли суб'єкт господарювання чи установа користується майном [13].

Раніше у законодавстві України містилась норма, згідно з якою публічні установи, які перебували на державному бюджеті і наділялися правом здійснювати господарську діяльність, мали право самостійного розпорядження доходами від такої діяльності та майном, придбаним за рахунок цих доходів. Вважаємо, що це був певний крок до лібералізації правового режиму майна публічних установ. Звідси випливає висновок про те, що правова конструкція права оперативного управління 
надає його носію правову можливість виокремлювати власне майно, яке належить на праві власності й іншій особі, залишаючи останній лише номінальне право, тобто право, позбавлене більшості правомочностей.

3 огляду на це можна зазначити, що господарські правовідносини щодо використання чужого майна за певних умов можна віднести до абсолютно-відносних правовідносин, які мають комплексний характер, щодо яких не може бути застосована дихотомія абсолютних та відносних правовідносин. У рамках організаційно-господарських відносин щодо використання чужого майна слід розрізняти такі відносини: а) які виникають у процесі управління чужим майном; б) організаційні відносини, які виникають у зв'язку з передачею майна від суб'єктів організаційно-господарських повноважень до суб’єктів господарювання (наприклад, уповноважений орган державної влади передає майно державному підприємству на праві оперативного управління); в) майнові відносини, які безпосередньо пов'язані з використанням чужого майна.

Отже, інститут оперативного управління майном проіснував декілька десятків років у незмінному вигляді. До того ж досвід ФРН також доводить життєздатність згаданого правового режиму, що за ознаками наближений до українського права оперативного управління. 3 огляду на це подальше дослідження питання правового режиму майна суб'єктів управління у державному секторі економіки є необхідним. Зазначене узгоджується із Стратегією підвищення ефективності діяльності суб’єктів господарювання державного сектору економіки, згідно з якою одним із основних заходів щодо підвищення ефективності діяльності суб'єктів господарювання є розроблення і впровадження основних засад політики власності, яка передбачає заходи щодо поліпшення корпоративного управління суб'єктами господарювання та чіткого розмежування функцій держави з управління об’єктами державної власності та регулювання ринку.

3 огляду на такі міркування підвищення ефективності діяльності суб'єктів управління у державному секторі економіки, на нашу думку, можливе шляхом закріплення на законодавчому рівні за ними права власності на доходи від власної господарської діяльності. Практична реалізація цієї пропозиції буде сприяти нормалізації участі державних установ у суспільних відносинах і мотивації ефективного управління майном на праві оперативного управління.

\section{Jimepamypa}

1. Конвенція про захист прав людини і основоположних свобод : Конвенція від 04.11.1950 р. Офіиійний вісник України. 16.04.1998. № 13. № 32.

2. Конституція України : Закон України від 28.06.1996 р. № 254к/96-ВР. Відолості Верховної Ради Украӥни. 1996. № 30. Ст. 141 (із змінами).

3. Господарський кодекс України : Закон України від 16 січня 2003 р. № 436-IV. Відомості Верховної Ради Украӥни. 2003. №№ 18-22. Ст. 144 (із змінами).

4. Про Кабінет Міністрів України : Закон України від 27 лютого 2014 року № 794-VII. Відомості Верховної Ради. 2014. № 13. Ст. 222.

5. Про схвалення стратегії підвищення ефективності діяльності суб’єктів господарювання державного сектору економіки : Розпорядження Кабінету Міністрів України від 27 травня 2015 року № 662-р. Oфiuійний вісник України. 17.07.2015. № 54. Ст. 1756.

6. Пронська Г.В. Вибране. Київ : Освіта України, 2013. $696 \mathrm{c}$.

7. Вінник О.М. Господарське право : навчальний посібник. 2-ге вид., змін. та доп. Київ : Всеукраїнська асоціація видавців «Правова єдність», 2008. 766 с.

8. Науково-практичний коментар Господарського кодексу України / Г.Л. Знаменський, В.В.Рахлін, В.С. Хахулін ; за ред. В.К. Мамутова. Київ, 2004. C. 219-220.

9. Цивільне право України. Частина перша : підручник для студентів юридичних спеціальностей вищих закладів освіти / Ч.Н. Азімов, М.М. Сібільов, В.І. Борисова та ін. ; за ред. проф. Ч.Н. Азімова, доцентів С.Н. Приступи, В.М. Ігнатенка. Харків : Право, 2000. 368 c.

10. Лещенко Д.С. Правовий статус установ в цивільному праві України : автореф. дис. ... канд. юрид. наук : 12.00.03. Харків, 2005. 28 с.

11. Захарченко A.M. Управління об'єктами державної власності (господарсько-правові аспекти) : монографія. Вінниця : ТОВ «Нілан-ЛТД, 2017. 452 с.

12. Bundeshaushaltsordnung / Бюджетний кодекс ФРН : нормативно-правовий акт ФРН від 19 серп. 1969 р. станом на 03.12.2015 p. / BGBl. I S. 1284.

13. Бобкова А.Г., Заруднєв Є.О. Щодо господарського відання та оперативного управління майном порівняно із законодавством ФРН. Вісник Наиіональної академії правових наук України. 2016. № 1 (84). C. 76-83. 


\section{Анотація}

Подоляк А. В. Правовий режим майна суб'єктів управління у державному секторі економіки. - Стаття.

У статті розглянуто питання особливостей правового режиму майна суб'єктів управління у державному секторі економіки, зокрема державних установ, досліджено законодавче закріплення регулювання відносин щодо створення юридичних осіб публічного права - установ, здійснення ними господарської діяльності у державному секторі економіки в Господарському кодексі України і Цивільному кодексі України. Опрацьовано особливості такого речового права на чуже майно, як право оперативного управління, яке становить основу правового режиму майна суб'єктів управління у державному секторі економіки. Проаналізовано генезу господарсько-правового регулювання закріплення майна за суб'єктами управління у державному сектоpi економіки. Доведено, що управління майном інших осіб завжди охоплює відносини між двома сторонами, одна 3 яких $є$ власником майна, що передається в управління, а інша - особою, яка реалізує майнове право власника шляхом використання правомочностей щодо володіння, користування й розпорядження майном у відповідному обсязі протягом певного терміну та видів господарських відносин щодо використання чужого майна за певних умов. Обгрунтовано, що використання чужого майна у сфері господарювання слід розглядати у різних значеннях економічного та правового характеру, в т.ч. як дії суб'єкта господарської діяльності щодо отримання корисних властивостей майна, яке належить іншій особі на праві власності.

У статті досліджується за допомогою порівняльно-правового методу законодавство зарубіжних країн щодо правового статусу юридичних осіб, заснованих державою. Іноземне законодавство порівнюється 3 національним законодавством.

Сформульовано пропозиції до чинного законодавства щодо вдосконалення вказаного інституту та запропоновано закріпити на законодавчому рівні визначення цього інституту через визнання за державними установами права власності на доходи від власної господарської діяльності.

Ключові слова: правовий режим, майно, суб'єкт господарювання, суб'єкт управління, публічна юридична особа, державна установа, некомерційна господар- ська діяльність, оперативне управління, господарське відання, право власності, економіка, правомочності власника.

\section{Summary}

Podoliak A. V. Legal regime of property of public entities in the public sector. - Article.

The article deals with the peculiarities of the legal regime of property which is possessed by the subjects of management in the public sector of economy, in particular, by the state institutions. The author focuses on current legal rules of the Commercial Code of Ukraine and the Civil Code of Ukraine for the creation, implementation of economic activity in the state sector of economy - regarding legal entities of public law - institutions. The article reveals the peculiarities of proprietary interests in other owner's assets, including the right of operational management. The article discusses over the genesis of economic and legal regulation of securing property by public sector entities, the author delivers arguments that other entity's property management always implies relations between two parties, one of which is the owner of the property and the other is the person who enforces the property right by using the powers to own, use and dispose of the property in respective scope for a certain period. It is substantiated that usage of other owner's assets in course of doing business should be considered in various economic and legal issues, including as actions of the subject of economic activity in obtaining useful properties of property owned by another person on the property. The author considers the types of economic relations on the use of someone else's property under certain conditions by using the comparative legal method with reference to the foreign law on the legal status of legal entities founded by the state and similar Ukraine's legislation. The author suggests proposals to improve the current legislation by introducing the legal principle that the state institutions shall have ownership title for the income gained in course of using and possessing the state property in their own economic activity.

Key words: legal regime, property, economic entity, management entity, public entity, government agency, non-commercial economic activity, operational management, economic management, ownership, economy, owner's powers. 